\begin{tabular}{lcl}
\hline Bentham OPEN & Open Medicine Journal \\
CrossMark & Content list available at: www.benthamopen.com/MEDJ/ & $\begin{array}{l}\text { Open } \\
\text { Medine } \\
\text { lournal }\end{array}$ \\
\hline
\end{tabular}

RESEARCH ARTICLE

\title{
Evaluation of 9 Rapid Agglutination Tests for the Diagnosis of Typhoid and Parathyphoid Fever in Côte D'ivoire
}

\author{
André Inwoley ${ }^{1,2,}$, Roseline Affi-Aboli ${ }^{1}$, Matthieu Kabran ${ }^{1,2}$, Aimé Césaire Adiko ${ }^{1}$, Nadège-Audrey \\ Abiyou ${ }^{1}$, Franck Stéphane Amani ${ }^{1}$, Jean-Claude Seka ${ }^{1}$ and Bamory Dembele ${ }^{1}$ \\ ${ }^{I}$ Immunology Unit, Faculty of Pharmaceuticals and Biological Sciences, University Felix Houphouet Boigny, Abidjan, \\ Côte D'ivoire \\ ${ }^{2}$ Centre for Diagnosis and Research on AIDS and other Infectious Diseases, Treichville, Abidjan, Côte D'ivoire
}

Received: September 01, 2016

Revised: September 24, 2016

Accepted: September 24, 2016

\section{Abstract:}

\section{Introduction:}

In Africa, the Widal test is done in the majority of laboratories by rapid tests whose performances are poorly documented. We evaluate the performance of 9 commercial rapid tests used in Côte d'Ivoire for the serodiagnosis of typhoid and paratyphoid fever.

\section{Methods:}

we used a panel of 170 samples collected from subjects suspected of typhoid or paratyphoid fever in Abidjan to determine the sensitivity, the specificity and operational characteristics of 9 plate agglutination tests $\left(\right.$ BIOREX $^{\circledR}$, BIOTEC $^{\circledR}$, CHRONOLAB $^{\circledR}$, CROMATEST $^{\circledR}$, FORTRESS $^{\circledR}$, PLASMATEC $^{\circledR}$, CYPRESS $^{\circledR}$, SPINREACT $^{\circledR}$ and TYDAL $^{\circledR}$ ) compared to the reference technique SALMONELLA SEROLOGY ${ }^{\circledR}$ of BIORAD (tube agglutination).

\section{Results:}

Among the 9 evaluated tests, only BIOTEC ${ }^{\circledR}$ presented good performances (96\% sensitivity and $97 \%$ specificity). Others gave sensitivities below $80 \%$. Their characteristics were improved with the semi-quantitative plate agglutination test. All tests had good operational characteristics.

\section{Conclusion:}

In our context, the majority of tests evaluated should not be used to carry out the Widal test.

Keywords: Assessment panel, Paratyphoid fevers, Sensitivity, Specificity, Typhoid Widal test.

\section{INTRODUCTION}

Typhoid and paratyphoid fevers are febrile, often systemic and serious diseases caused by Salmonella enterica of typhi and paratyphi serotyp. They are a major public health problem, especially in developing countries. In effect, Crump et al. estimated at approximately 21.650 million the number of cases of typhoid fever with approximately 200000 deaths in 2000 [1,2]. Africa, where the faecal peril is the cause of the transmission through water or contaminated food, remains an area of high endemicity with an overall incidence rate estimated at 724.6 per 100000 person-years $[1,3]$.

\footnotetext{
* Address correspondence to this author at the Immunology Unit, Faculty of Pharmaceuticals and Biological Sciences, University Felix Houphouet Boigny, BP V 34 Abidjan, Côte D'ivoire; Tel: (225) 05058587; E-mail: andre.inwoley@gmail.com
} 
Without an effective treatment, typhoid fever has a mortality rate of $10-30 \%$. This number is reduced to $1-4 \%$ for those receiving appropriate treatment [1]. In Côte d'Ivoire, the mortality rate was estimated at 5\% [4].

An accurate, rapid diagnosis and an early treatment with appropriate antibiotics are essential for rapid recovery and the prevention of complications and deaths caused by this disease and also for the control of the transmission.

The diagnosis of typhoid fever on clinical grounds is difficult, because symptoms are many and similar to those of other common febrile disease, such as malaria and non-severe dengue fever [5].

Although the isolation of Salmonella typhi from the bone marrow is the reference method to confirm a case of typhoid fever, blood culture is more often used as a much more convenient alternative [6]. However, because of the availability period of results (2-3 days) the diagnosis may be delayed or neglected and patients without typhoid fever may receive an unnecessary and inappropriate antibiotic treatment [7].

A simpler method for the diagnosis of typhoid fever, based on the detection of antibodies, Widal test, widely used in countries with limited resources for more than a century [8], has the advantage of quickly providing a result. This test remains the most economical means of diagnosis. However, false positive results are common because of the cross antigenic reactivity of Salmonella with other infectious agents, Enterobacteriaceae, and in cases with patients with a history of diseases such as malaria, dengue and typhoid fever [2, 9, 10].

The Widal test can be performed in the tube and on slide [10]. The tube agglutination, allows reliable results, but its realization is longer and requires technical mastery. So, a particular interest was developed for the slide agglutination method by several manufacturers. Different works record that Widal tests present quite variable performances [7, 11, 12], hence the interest to carry out assessments before they are used in a given context.

The aim of our study was to evaluate commercial rapid Widal test commonly used in health facilities of Abidjan.

\section{MATERIAL AND METHODS}

This cross-sectional study was carried out from February to August 2011 at the Centre for Diagnosis and Research on AIDS and other infectious diseases located at the University Hospital of Treichville, Abidjan.

\subsection{Assessment Panel}

This study was carried out on 170 sera, which constitutes the assessment panel. These samples were collected in health centres of Abidjan, which performed the Widal test through plate agglutination technique. These samples were taken from febrile patients suspected to have typhoid fever and whose thick-drop malaria diagnosis was negative.

The collected sera were sent the same day and stored at $-20^{\circ} \mathrm{C}$ until the evaluation date at the Centre for Diagnosis and Research on AIDS and other infectious diseases located in the University Hospital of Treichville.

\subsection{Evaluation}

All sera were tested in parallel with the tube agglutination test SALMONELLA SEROLOGY of BIORAD ${ }^{\circledR}$ (BioRad Laboratories. Inc.) used as reference test and the rapid agglutination tests on plate or slide to be evaluated were the following: BIOREX ${ }^{\circledR}$ (Biorex Diagnostics Limited, UK), BIOTEC ${ }^{\circledR}$ (BIOTEC Laboratories Ltd, UK), CHRONOLAB ${ }^{\circledR}$ (CHRONOLAB SYSTEMS S.L. Barcelona, Spain), CROMATEST ${ }^{\circledR}$ (Linear Chemicals, Barcelona, Spain), FORTRESS $^{\circledR}$ (Fortress Diagnostics Limited, UK), PLASMATEC ${ }^{\circledR}$ (Plasmatec Laboratory Products, UK), CYPRESS (Cypress Diagnostics, Belgium), SPINREACT ${ }^{\circledR}$ (SPINREACT, S.A, Spain) and TYDAL ${ }^{\circledR}$ (TULIP DIAGNOSTICS (P) Ltd, India). The characteristics of these tests are: (i) the storage temperature: $2-8^{\circ} \mathrm{C}$; (ii) the reading is visual. Tests were performed according to the manufacturer's recommendations. Appropriate positive and negative control sera were included.

For the tube technique, the mixture of $0.9 \mathrm{ml}$ of antigenic suspension $(\mathrm{O}$ and $\mathrm{H})$ and $0.1 \mathrm{ml}$ of a dilution of serum $(1 / 10$ or $1 / 20)$ is centrifuged at $3000 \mathrm{rpm}$ for $5 \mathrm{~min}$. The positive reaction is characterized by agglutination. When the reaction was positive, we performed titration by carrying out increasing dilutions. The title was the opposite of the last positive dilution.

In the plate technique, we successively conducted the qualitative and semi-quantitative methods. For the qualitative method; on a plate, we mixed $50 \mu \mathrm{l}$ of the test serum and $50 \mu \mathrm{l}$ of the antigenic suspension. After shaking for about 2 minutes, the presence of agglutinate in the test area shows a positive result. In the semi-quantitative method, we added 
$50 \mu \mathrm{l}$ of antigenic suspension to the increasing quantities of serum 5, 10, 20, 40 and $80 \mu 1$, homogenized and sought for an agglutination after 2 minutes. Agglutination corresponds to respective titers of 320, 160, 80, 40 and 20.

Titres above 80 for rapid plate tests and 200 for the BIORAD test were considered positive.

\subsection{Analysis of Performances}

The sensitivity and specificity of the diagnostic tests were calculated using standard formulas to determine the diagnostic accuracy of the 9 tests. The SALMONELLA SEROLOGY of BIORAD ${ }^{\circledR}$ test result was taken as the reference standard.

\section{RESULTS}

The widal test with single tube, reference standard, allowed to define the status of the 170 sera. The panel included 119 negative samples and 51 positive samples. Anti-TH antibody was the most frequently detected antibody followed by anti-TO (Table 1).

Table 1. Characteristics of the evaluation panel.

\begin{tabular}{|c|c|c|}
\hline & \multicolumn{2}{|c|}{ Positives for the type of antibody } \\
N=170 \\
\hline Antigens & Size & Percentage \\
\hline TO & 15 & 8,8 \\
\hline TH & 39 & 22,9 \\
\hline AO & 1 & 0,6 \\
\hline AH & 4 & 2,4 \\
\hline BO & 5 & 2,9 \\
\hline BH & 5 & 2,9 \\
\hline CO & 5 & 2,9 \\
\hline CH & 8 & 4,7 \\
\hline
\end{tabular}

The overall technical performances of the 9 tests according to the qualitative and semi-quantitative agglutination are summarized in Table 2. With the qualitative agglutination, only the BIOTEC ${ }^{\circledR}$ test had a sensitivity up to $90 \%$, while SPINREACT $^{\circledR}$ and CHRONOLAB $^{\circledR}$ have specificities more than $90 \%$. The discordant rate between plate agglutination test and the reference test ranged from $20 \%$ for SPINREACT ${ }^{\circledR}$ to nearly $49 \%$ for BIOREX ${ }^{\circledR}$. The semi-quantitative plate agglutination gave higher specificities compared to the qualitative method and lower discordant percentages. Performances of the tests to detect several antibodies (somatic or flagellar for Salmonella species) are presented in Table 3. Sensitivities for the detection of flagellar $(\mathrm{H})$ and somatic $(\mathrm{O})$ antibodies of Salmonella typhi and S. paratyphi were bad with the two methods for all tests. Specificities increased with the semi-quantitative technique. However, they were more than $90 \%$ for FORTRESS ${ }^{\circledR}$ and BIOTEC $^{\circledR}$ testing for the detection of anti-TO antibodies.

For operational caracteristics, all tests were simple, easy and quick to perform.

Table 2. Global performance of the evaluated tests.

\begin{tabular}{|c|c|c|c|c|c|c|}
\hline & \multicolumn{3}{|c|}{ QUALITATIVE METHOD } & \multicolumn{3}{c|}{ SEMI-QUANTITATIVE METHOD } \\
\hline RAPID TESTS & Sensitivity (\%) & Specificity (\%) & Discordance (\%) & Sensitivity (\%) & Specificity (\%) & Discordance (\%) \\
\hline BIOTEC & 96,1 & 46,2 & 38,8 & 96,1 & 96,6 & 3,5 \\
\hline CROMATEST & 68,6 & 72,3 & 28,8 & 66,7 & 98,3 & 11,2 \\
\hline FORTRESS & 80,4 & 56,3 & 36,4 & 80,4 & 89,9 & 12,9 \\
\hline TYDAL & 72,5 & 54,6 & 40,0 & 72,5 & 91,6 & 14,1 \\
\hline CHRONOLAB & 49,0 & 91,6 & 21,2 & 49,0 & 99,2 & 15,4 \\
\hline CYPRESS & 58,8 & 69,7 & 33,5 & 58,8 & 94,9 & 15,9 \\
\hline PLASMATEC & 66,7 & 62,2 & 36,5 & 62,7 & 93,3 & 15,9 \\
\hline SPINREACT & 45,1 & 95,0 & 20,0 & 45,1 & 99,1 & 17,0 \\
\hline BIOREX & 66,7 & 44,5 & 48,8 & 66,7 & 84,0 & 21,2 \\
\hline
\end{tabular}




\section{DISCUSSION}

Typhoid fever occurs more often in areas with precarious lifestyle.

The isolation of bacteria from the blood or bone marrow is the "gold standard" for diagnosis, but the cost of culture equipment and facilities limit its practice in primary and secondary health facilities where the diagnostic tool of choice remains the Widal and Felix Serodiagnostic testing. We considered the Widal test with single tube as a reference test even if some authors $[13,14]$ report that the Widal test has a low sensitivity and specificity compared to blood culture. The sensitivity of the latter is known to be less than $100 \%$, even in the absence of exposure to antibiotics whose usage leads often to negative culture results $[2,7]$.

Our study showed that evaluated tests have poor sensitivity both with the qualitative and the semi-quantitative method, except for BIOTEC ${ }^{\circledR}$ test. The discordance rate (between evaluated and reference test) was variable from one test to another. This could be due to the diversity of antigenic preparations [15], suggesting that in a same study, the results would not be comparable between sites as reported by Wafaa et al. [16]. Even if it shows a good sensitivity, the BIOTEC $^{\circledR}$ test presented a low capacity to detect specific somatic and flagellar antibodies of Salmonella species. In addition, we found that anti-H antibodies were more sensitive and more specific than anti-O antibodies regardless of the method and the test on the threshold of 1/80. By cons, Bakr et al. showed that agglutinins $\mathrm{H}$ were less sensitive and less specific than agglutinins $\mathrm{O}$ at the cut-off value of 1/80 [16]. However, for Parry et al. even if agglutinins $\mathrm{H}$ were less sensitive, they were more specific than agglutinins $O$ and gave the best positive predictive value [17]. Thus, the titer of agglutinins $\mathrm{H}$ would be as useful or more useful than the titre of agglutinins $\mathrm{O}$ [18].

Table 3. Performances of tests for the detection of somatic and flagellar antibodies of Salmonella typhi.

\begin{tabular}{|c|c|c|c|c|c|}
\hline & & \multicolumn{2}{|c|}{ Sensitivity (\%) } & \multicolumn{2}{c|}{ Specificity (\%) } \\
\hline & Antigen & Qualitative method & Semi-quantitative method & Qualitative method & Semi-quantitative method \\
\hline CROMATEST & TO & 13,3 & 0,0 & 89,7 & 96,8 \\
\hline & TH & 71,8 & 46,2 & 76,3 & 94,7 \\
\hline PLASMATEC & TO & 46,7 & 20,0 & 72,9 & 92,3 \\
\hline & TH & 66,7 & 53,8 & 78,6 & 96,2 \\
\hline FORTRESS & TO & 46,7 & 26,7 & 72,9 & 96,5 \\
\hline & TH & 56,4 & 38,5 & 74,8 & 93,6 \\
\hline BIOTEC & TO & 20,0 & 20,0 & 74,2 & 95,4 \\
\hline & TH & 74,4 & 71,8 & 74,8 & 93,5 \\
\hline TYDAL & TO & 33,3 & 20,0 & 88,5 & 98,5 \\
\hline & TH & 53,8 & 30,8 & 81,9 & 96,1 \\
\hline CYPRESS & TO & 26,7 & 13,3 & 84,7 & 96,2 \\
\hline & TH & 61,5 & 35,9 & 87,7 & 95,5 \\
\hline SPINREACT & TO & 46,7 & 26,7 & 96,2 & 100,0 \\
\hline & TH & 61,5 & 30,8 & 51,0 & 80,6 \\
\hline BIOREX & TO & 20,0 & 6,7 & 75,6 & 96,9 \\
\hline & TH & 61,5 & 41,0 & 86,5 & 95,5 \\
\hline CHRONOLAB & TO & 46,7 & 26,7 & 93,9 & 99,2 \\
\hline & TH & 59,0 & 28,2 & & \\
\hline
\end{tabular}

Our results show that the poor specificity observed with the qualitative agglutination was improved with the semiquantitative agglutination. High false-positive rates show the limits of the qualitative agglutination test while it is the most common technique in laboratories using these tests in Abidjan, Côte d'Ivoire. As a result, the qualitative slide agglutination test should not be used as a diagnostic tool.

The titration of antibodies recommended by manufacturers allows to reduce the rate of false positives and to determine the more specific serological diagnosis [17]. Several factors can affect the performance of the evaluated tests: (i) some healthy populations have agglutinins that can be detected at variable high rates $[17,18]$. (ii) the high rate of reactions crossed with some pathogens encountered in endemic areas (example: malaria) increases the probability to have false positive results [10]. Thus, some authors recommend an increase of the title of positivity [17, 19, 20] to improve the specificity of the Widal tests. 
We took a single sample by participant while the initial Widal agglutination test has been described by using pairs of sera obtained between a period of 10 days to 2 weeks and examined for a double or more change of the antibody title [21]. It is possible that the Widal test would have had better results in our study if we used paired sera, but we chose to apply the test in conditions that are normally found in clinical practice. In our experience, patients rarely come back for outpatient aftercare, once treated, so that getting paired sera in a routine clinical framework is unlikely. Recently, the use of pairs of sera was reexamined and was shown to improve the sensitivity and specificity of serological tests for typhoid fever [22].

All evaluated tests are simple to carry out, that is why they are used in the majority of biology laboratories of health facilities of primary and secondary levels of the health pyramid in Côte d'Ivoire. However, the practice of Widal test could be influenced by the understanding of the instructions contained in the operating instructions written in English (operating procedures, reagents, interpretation of results).

Our results suggest that among the 9 tests, only the BIOTEC ${ }^{\circledR}$ test may be recommended as first choice for the serological diagnosis of salmonellosis.

However, it is essential to carry out the semi-quantitative slide agglutination when the qualitative agglutination is positive, then determine the specificity of antibodies with another test as the reference test used in our study.

\section{CONCLUSION}

This study allowed us to show the interest to evaluate the tests for serological diagnosis of typhoid fever. Indeed, among the 9 tests commonly used in Côte d'Ivoire, only one gave good performances. Thus, the need for rapid and cheap diagnosis tools with best performances still topical .

\section{CONFLICT OF INTEREST}

The authors confirm that this article content has no conflict of interest.

\section{ACKNOWLEDGEMENTS} testing.

We thank laboratory staff of the health facilities for providing specimen and for their assistance with laboratory

\section{REFERENCES}

[1] Crump JA, Luby SP, Mintz ED. The global burden of typhoid fever. Bull World Health Organ 2004; 82(5): 346-53. [PMID: 15298225]

[2] Parry CM, Hien TT, Dougan G, White NJ, Farrar JJ. Typhoid fever. N Engl J Med 2002; 347(22): 1770-82. [http://dx.doi.org/10.1056/NEJMra020201] [PMID: 12456854]

[3] Buckle GC, Walker CL, Black RE. Typhoid fever and paratyphoid fever: Systematic review to estimate global morbidity and mortality for 2010. J Glob Health 2012; 2(1): 010401 [http://dx.doi.org/10.7189/jogh.01.010401] [PMID: 23198130]

[4] Coulibaly M, Eholie S, Okome NM, et al. Ofloxacine dans le traitement de la fièvre typhoïde en milieu hospitalier CHU de Treichville—Abidjan—Côte d'Ivoire. Med Afr Noire 1992; 39(7): 531-4.

[5] Stuart BM, Pullen RL. Typhoid; clinical analysis of 360 cases. Arch Intern Med (Chic) 1946; 78(6): 629-61 [http://dx.doi.org/10.1001/archinte.1946.00220060002001] [PMID: 20278487]

[6] Wain J, Hosoglu S. The laboratory diagnosis of enteric fever. J Infect Dev Ctries 2008; 2(6): 421-5. [PMID: 19745517]

[7] Keddy KH, Sooka A, Letsoalo ME, et al. Sensitivity and specificity of typhoid fever rapid antibody tests for laboratory diagnosis at two subSaharan African sites. Bull World Health Organ 2011; 89(9): 640-7. [http://dx.doi.org/10.2471/BLT.11.087627] [PMID: 21897484]

[8] Schroeder SA. Interpretation of serologic tests for typhoid fever. JAMA 1968; 206(4): 839-40. [http://dx.doi.org/10.1001/jama.1968.03150040051012] [PMID: 5695671]

[9] Ohanu ME, Mbah AU, Okonkwo PO, Nwagbo FS. Interference by malaria in the diagnosis of typhoid using Widal test alone. West Afr J Med 2003; 22(3): 250-2 [PMID: 14696952]

[10] Olopoenia LA, King AL. Widal agglutination test - 100 years later: still plagued by controversy. Postgrad Med J 2000; 76(892): 80-4. [http://dx.doi.org/10.1136/pmj.76.892.80] [PMID: 10644383] 
[11] Kawano RL, Leano SA, Agdamag DM. Comparison of serological test kits for diagnosis of typhoid fever in the Philippines. J Clin Microbiol 2007; 45(1): 246-7. [http://dx.doi.org/10.1128/JCM.01403-06] [PMID: 17065261]

[12] Olsen SJ, Pruckler J, Bibb W, et al. Evaluation of rapid diagnostic tests for typhoid fever. J Clin Microbiol 2004; 42(5): 1885-9. [http://dx.doi.org/10.1128/JCM.42.5.1885-1889.2004] [PMID: 15131144]

[13] Hamze M, Naboulsi M, Vincent P. Evaluation of the Widal test for diagnosing typhoid fever in Lebanon. Pathol Biol (Paris) 1998; 46(8): 613-6. [PMID: 9871933]

[14] Kariuki S, Mwituria J, Munyalo A, Revathi G, Onsongo J. Typhoid is over-reported in Embu and Nairobi, Kenya. Afr J Health Sci 2004; 11(3-4): 103-10 [PMID: 17298127]

[15] Agbenu E, d'Almeida H, Kolou M, et al. Evaluation of the Widal-Felix serodiagnostic test in Togo. Médecine Trop Rev Corps Santé Colon 2010; 70: 43-8.

[16] Bakr WM, El Attar LA, Ashour MS, El Toukhy AM. The dilemma of widal test - which brand to use? a study of four different widal brands: a cross sectional comparative study. Ann Clin Microbiol Antimicrob 2011; 10 : 7. [http://dx.doi.org/10.1186/1476-0711-10-7] [PMID: 21303511]

[17] Parry CM, Hoa NT, Diep TS, et al. Value of a single-tube widal test in diagnosis of typhoid fever in Vietnam. J Clin Microbiol 1999; 37(9): 2882-6. [PMID: 10449469]

[18] Coovadia YM, Singh V, Bhana RH, Moodley N. Comparison of passive haemagglutination test with Widal agglutination test for serological diagnosis of typhoid fever in an endemic area. J Clin Pathol 1986; 39(6): 680-3. [http://dx.doi.org/10.1136/jcp.39.6.680] [PMID: 2424936]

[19] Ley B, Mtove G, Thriemer K, et al. Evaluation of the Widal tube agglutination test for the diagnosis of typhoid fever among children admitted to a rural hdospital in Tanzania and a comparison with previous studies. BMC Infect Dis 2010; 10: 180. [http://dx.doi.org/10.1186/1471-2334-10-180] [PMID: 20565990]

[20] Hosoglu S, Geyik MF, Akalin S, Ayaz C, Kokoglu OF, Loeb M. A simple validated prediction rule to diagnose typhoid fever in Turkey. Trans R Soc Trop Med Hyg 2006; 100(11): 1068-74. [http://dx.doi.org/10.1016/j.trstmh.2005.12.007] [PMID: 16697432]

[21] Widal F. Serodiagnostic de la fièvre typhoide à-propos d'une modification par M. M. C. Nicolle et A. Halipre. Bull Mem Soc Med Hop Paris 1896; 13: 561-6.

[22] House D, Chinh NT, Diep TS, et al. Use of paired serum samples for serodiagnosis of typhoid fever. J Clin Microbiol 2005; $43(9)$ : 4889-90. [http://dx.doi.org/10.1128/JCM.43.9.4889-4890.2005] [PMID: 16145168]

(C) Inwoley et al.; Licensee Bentham Open

This is an open access article licensed under the terms of the Creative Commons Attribution-Non-Commercial 4.0 International Public License (CC BY-NC 4.0) (https://creativecommons.org/licenses/by-nc/4.0/legalcode), which permits unrestricted, non-commercial use, distribution and reproduction in any medium, provided the work is properly cited. 